\title{
CASE STUDY METHODOLOGY AS AN EDUCATIONAL TOOL FOR FASHION BUSINESS MANAGEMENT
}

\author{
Verónica Arribas \\ Isabel García Hiljding \\ Lourdes Susaeta \\ José Ramón Pin Arboledas
}




\title{
CASE STUDY METHODOLOGY AS AN EDUCATIONAL TOOL FOR FASHION BUSINESS MANAGEMENT
}

\author{
Verónica Arribas ${ }^{1}$ \\ Isabel García Hiljding ${ }^{2}$ \\ Lourdes Susaeta ${ }^{3}$ \\ José Ramón Pin Arboledas ${ }^{4}$
}

\begin{abstract}
During the past decade the fashion industry has changed dramatically. It is entering the most complex and sophisticated business situation seen so far. Tough strategic and managerial challenges continuously test fashion companies' strength. Thus, in order to continue progressing in the industry, future managers should be very well prepared to deal with this complex situation and trained so they can make the correct decisions in all the trade-off choices they will encounter.
\end{abstract}

Bearing in mind this complex situation for the industry, our fashion business school advocates the use of the case method as the main educational tool in all the programs offered. Used first by Harvard Business School and now used in almost all the best business schools worldwide, this method is a very effective educational tool that presents great challenges faced by real companies and encourages the student to adopt the role of the company's decision-maker.

The main objective of this paper is to introduce the benefits of fashion business education using real company cases, as well as to recommend this as a reliable learning method for this industry. To do this, we will: (1) explain what this method is and how it should be used in order to be effective, (2) explain why we consider the use of this method to be relevant, particularly in fashion business education, (3) share both our experience as a fashion business school - through teaching and writing fashion company case studies - and the feedback provided by some of our former students, most of them working in executive positions in major fashion companies.

In addition, we will encourage the publication of new cases that present real challenges currently faced by companies in this industry. We believe that sharing business experiences can be a very good way for us all to contribute to ensure the whole industry functions well.

JEL Classification: I29

Keywords: Fashion management, Fashion education, Case method, Fashion industry, Fashion business school

\footnotetext{
${ }^{1}$ PhD Candidate, ISEM Fashion Business School, University of Navarra, varribas@alumni.unav.es.

${ }^{2}$ PhD Candidate, ISEM Fashion Business School, University of Navarra.

${ }^{3}$ Professor ISEM Fashion Business School, University of Navarra.

${ }^{4}$ Professor, Managing People in Organizations, Business Ethics, IESE.
} 


\section{CASE STUDY METHODOLOGY AS AN EDUCATIONAL TOOL FOR FASHION BUSINESS MANAGEMENT}

\section{INTRODUCTION}

The aim and challenge of every business school is to prepare students in the best way possible for the real world of work. Students preparing to work in a business environment must learn how to identify difficulties, how to make decisions and how to act - that is, how to deal with real problems and situations in a company.

In the particular case of the fashion industry, we can see that it has changed dramatically during the past decade and that it is entering the most complex and sophisticated business situation seen so far. Therefore, in order to continue progressing in the industry, future managers should be very well prepared to deal with this complex situation and trained so they can make the correct decision in all the trade-off choices they will encounter. To achieve this goal we believe the case study is suitable as a relevant teaching method and we want to share here our experience as a fashion business school when using this method as the main element in our programs.

With this paper, we would like to contribute to the educational literature in fashion business schools by illustrating the usefulness of applying this methodology. We also want to encourage fashion schools worldwide to write new cases specializing in the fashion industry and create a community between schools in order to write cases together and offer fashion students a global perspective on this ever-changing industry.

Regarding the methodology applied in the paper, we have chosen three different case studies, all of them written and developed in our business school. In order to strengthen our proposition in this article, we have examined whether former students also find this method useful when learning fashion business management. We have asked them several questions about the three cases and the result is very positive and encouraging.

The structure of the paper begins with a literature review of the case study method. It continues by explaining how the method is applied, how it differs from the traditional teaching approach, its effectiveness, the challenges and the limitations found. In the next point we try to explain the appropriateness of applying this method in the fashion business, and characteristics such as creativity are analyzed briefly in order to understand the particular nature of the industry. The third part of the paper focuses on sharing both our experience as a fashion business school through teaching and writing fashion company case studies - and the feedback provided by some of our former students. The paper finishes with some conclusions and remarks about the limitations of this investigation. 


\section{THE CASE STUDY AS A LEARNING TOOL}

"The purpose of business education," noted a business school professor more than 80 years ago, "is not to teach truths [...] but to teach men [and women] to think in the presence of new situations” (Dewing, 1931).

As mentioned, the aim and challenge of every business school is to prepare students in the best way possible for the real world of work. Therefore, time in the classroom has to be used in the most effective manner, not only to transmit theory and concepts but also to translate these into real situations. Students preparing to work in a business environment must learn how to identify difficulties, how to make decisions and how to act - that is, how to deal with real problems and situations in a company.

How to develop these skills is the question we want to address in the first part of the paper. Which method is best for teaching in business studies courses, especially when they focus on the practical or professional side? What are the benefits of using the case method and how does it differ from traditional ways of teaching business issues?

\subsection{The Case Method: History and Adoption by Business Schools}

Many professional schools - not only in the discipline of business but also law, medicine, social sciences, mathematics and the arts - advocate that the best way to teach the professional skills needed is through the case method (Garvin, 2003; Golich, 2000).

This method - as we know it today - was first used in 1870 in Harvard Law School and although the aim and general operation remain the same, the approach and structure have developed and are adapted to the different learning goals (Garvin, 2003). It was so different from the method being used at that time by law schools - a combination of lectures, recitation and simulation that it faced a lot of resistance in the beginning. The main innovation behind it was the emphasis on legal process and judicial reasoning, thus preparing students to deal with the unknown and with changing circumstances (Garvin, 2003).

In spite of this initial resistance, the case method was accepted eventually and it became the dominant form of legal education by 1920. In that same year, Harvard's business school founded in 1908 - also adopted the case study method, encouraged by its second dean, Wallace B. Donham, a Harvard Law School graduate. However, Donham realized that the business school had to develop more cases of its own, which should differ from legal ones by taking greater account of the main skills needed in business: decision-making and implementation - often in uncertain conditions. With this aim, cases should present and describe in detail real situations for students to assess different problems and decide appropriately among more than one possible option. So that cases could be developed and written for different courses, the new dean established, from 1920 to 1925, the Bureau of Business Research - a group of scholars dedicated to this task. By 1930, cases had become the main teaching method and were adopted also by another 85 institutions. Nowadays, almost every business school around the world uses them in its programs (Garvin, 2003). 


\subsection{What the Case Teaching Method Is All About}

Modern cases ${ }^{1}$ still meet the basic features from the method's inception. They are stories that recreate the managers' job: they describe real companies and real business issues, forcing students to experience complex situations and to assume the role of the main character who has to make critical decisions (Garvin, 2003; Golich, 2000).

By using cases as the main teaching method for a course, we help students develop three important sets of skills: (1) diagnostic skills in an ever-changing environment, (2) persuasive skills, which seem to be necessary when it is considered that management is a "social art" with people behind it, and finally (3) distinctive ways of thinking and acting (Garvin, 2003). Cases teach students competencies inherent to these general skills: how to identify important information, how to understand problems with their context and variables, how to think about alternatives as well as how to define strategies and action plans (Golich, 2000). In the end, with the case system, students are made accustomed to making decisions and are encouraged to take risks and act in uncertain conditions and with limited knowledge (Garvin, 2003).

Despite there being well-known benefits to using this learning method, this does not mean that it is better than others. In fact, the perfect learning method depends on the course or subject and the method should fit the goals of the topic (Bonoma, 1989). Thus, when the goal or criterion of learning is fostering independent thinking, creativity and judgment or skill building and problem solving by offering complex real-world phenomena to study, a nontraditional way of learning is needed. This happens for instance in practical-focused business education, in which "experiential learning" is a better fit. Although there are many useful kinds of experiential learning, the most commonly used and highly regarded of them is the case study method (Bonoma, 1989; Ellet, 2007).

This method offers the student and practitioner a legitimate learning vehicle (Bonoma, 1989; Roberts, 2001). Nevertheless, cases do not seek to substitute textbooks, teaching notes or theories and assumptions but should complement these (Golich, 2000): cases teach the application of those concepts and theories (Ellet, 2007). In this way, the student learns not only what to think but also how to think regarding real business issues (Roberts, 2001).

\subsection{Differences From the Traditional Approach}

"The case plan of instruction may be described as democratic in distinction to the lecturing method, which is in effect dictatorial or patriarchal... Business is not, at least not yet, an exact science. There is no single, demonstrably right answer to a business problem. For the [manager] it cannot be a matter of peeking in the back of a book to see if he [or she] has arrived at the right solution. In every business situation, there is always a reasonable possibility that the best answer has not yet been found - even by the teachers" (Gragg, 1940).

Case teaching is learner-centered: the main characteristic is the high level of interaction both between the teacher and students and among them (Golich, 2000). Thus, traditional studentteacher roles - with their emphasis on hierarchy - are abandoned (Applegate, 1995) and the learning pathway changes from a straight way (in traditional learning) to a less linear way (in case teaching) (Golich, 2000).

\footnotetext{
${ }^{1}$ We should differentiate research cases from teaching cases. Teaching cases "just tell the story: what happened, who was involved, what they contended with, and, sometimes, how it came out" (from John Boehrer [1995-96]: "How to Teach a Case," Public Service Curriculum Exchange, \#N18-95-1285.0, Seattle: University of Washington. p. 2).
} 
While traditional teaching depends heavily on the teacher transmitting information in an interesting and clear way (Golich, 2000), in the case method the teacher is a "guide on the side" or "choreographer" (Golich, 2000); he or she is the discussion leader who serves as a recorder and organizer of the group's analysis and drives students towards not only diagnosis but also action (Bonoma, 1989).

Concerning students' role, in traditional learning they are "stenographers" and they have to process and retain information from the teacher (Golich, 2000). On the contrary, within the case teaching method, their role comes to the fore and they decide what "the right answer" is through deliberation, debate, and discussion (Bonoma, 1989). In fact, here is the true power of the case study (Bonoma, 1989) and the central characteristic of this method: the significant responsibility that is given to students (Golich, 2000; Ellet, 2007; Applegate, 1995). This means that the case method is about collaboration and its success is positively related to the degree of responsibility assumed by students and their willingness to take risks and participate toward the best understanding of the case situation (Ellet, 2007). However, it means that faculty must be prepared to relinquish "control” while still providing the needed framework for learning (Applegate, 1995).

\subsection{Effectiveness, Challenges and Limitations}

The case method is assumed to be more effective because "in the case method, birds learn to fly; with other techniques, they are often given an airline pass" (Bonoma, 1989).

The effectiveness of the case method when trying to achieve business learning objectives is associated largely with the degree of students' personal identification with the case protagonist and decision-maker. This identification is the main source of the powerful energy that drives preparation and discussion - from both students and instructors (Roberts, 2001; Bonoma, 1989) which is huge, compared with that of the traditional method. This way, students discover and construct knowledge in an active way and based on real facts and evidence, which has more sticking power than knowledge received directly from the teacher (Golich, 2000).

However, the potential of the case method's teaching power can vary in each case, depending on the variables that influence the discussion, which usually are: the teacher conducting the discussion, the case chosen, the students themselves and their motivation, and other issues relating to the surroundings such as the physical setting, time of day, etc. (Ellet, 2007). Due to this high level of enthusiasm and insight brought to the discussions and the dependence on the variables noted above, teaching using the case method is considered to be one of the most challenging forms of pedagogy (Applegate, 1995).

Here we can see how Prof. C. Roland Christensen, a master case teacher, emphasized the challenges and rewards of the method (Applegate, 1995):

"The classroom encounter consumes a great deal of energy; simultaneous attention to process (the flow of activities that make up a discussion) and content (the material discussed) requires emotional as well as intellectual engagement... The discussion teacher is planner, host, moderator, devil's advocate, fellow-student, and judge - a potentially confusing set of roles. Even the most seasoned group leader must be content with uncertainty, because discussion teaching is the art of managing spontaneity.” 
Yet, when something is challenging it is usually because it may have some limitations that have to be taken into account in order to maintain its effectiveness. From direct observation - of a three-week executive program - Harvard professor Chris Argyris (1980) extracted some of these limitations to bear in mind when using the case method. One risk he noted is the possible "loss of discussion control" by the teacher using the case, arguing that when the teacher was not very involved in the dialogue, students got distracted and started to carry on a "parallel dialogue" with other students. This independence grew the more student-to-student responses there were (Argyris, 1980). Accordingly, other possible harmful behavior might arise due to competitiveness. Sometimes students compete for "air time" (Yeaple, 2012), which can tempt them to select or distort information "to win" (Argyris, 1980). Another limitation concerning students is that, in order for them to contribute and profit more from this learning methodology, it is better that they have had some previous work experience (Yeaple, 2012). This limitation is well known and it has even become a basic criterion to enroll in an MBA course in almost every business school. Finally, two more possible drawbacks teachers must bear in mind when they decide to use the case method are: first, it may not be an efficient way to teach technical material or "unique correct answer" subjects and, second, there may be cases that are several years old and where the information or situation is irrelevant to the current business environment (Yeaple, 2012).

All these possible disadvantages may lead us to conclude that this is a "serious" method and not as easy and superfluous as it might seem. Thus, in order to use it properly and efficiently, the teacher must know how to use the case method very well, how it really works and the different strategies (Yeaple, 2012) that can be followed. It is also true that schools should always keep an eye on theory when advocating the case method. In fact, leading business schools are following this idea and using a balance of lectures to present the fundamentals and cases to see whether students have understood the fundamentals well enough and would be able to apply them to real management problems (Yeaple, 2012). In the end, this method is seen as the best way to give students hands-on experience while they are studying.

\section{THE CASE STUDY METHOD FOR FASHION BUSINESS EDUCATION}

The fashion industry is one of the most vibrant and creative sectors in the world. When creativity meets business, the result is truly unique but at the same time challenging because of the continuing restructuring and modernization of the industry. In a few decades it has changed radically in terms of logistics, design, retail, etc. One example of these changes results from digitization - what was inconceivable to us once no longer is. For instance, nowadays it is not necessary to go to the store to buy something. After clicking on your phone from the couch you can receive your chosen purchase at home in a couple of days. These changes become ongoing challenges for companies, which also must try to keep up as far as possible. In Europe, this industry directly employs five million people in approximately 850,000 companies. It provides an important contribution to the EU economy, with an annual turnover of $€ 525$ billion.

In our fashion business school, creativity is one of the main pillars. Thus, we advocate the importance of the creative aspects even when teaching fashion business management. One of the many definitions of creativity is the one given by Herbert Simon (1985), who argues that creativity consists of good problem solving (Santagata, 2004). We found this definition very interesting also when talking about the application of the case method in fashion business schools, because that is precisely what this method aims to do: to solve a company's real 
problems. Simon continues by saying that the process that leads to creativity is based on three conditions:

1. Being prepared: a casual discovery per se does not exist. There are no surprises without expectations, or expectations without knowledge.

2. Being experts: excellence is not possible without an intensive effort to acquire knowledge and skills.

3. Taking risks: neither fashion nor business is an exact science. It is necessary to take risks in order to explore new fields in a creative way.

Referring to the case study method explained above, we can observe the similarity with the creative process: (1) being prepared - the need to study and prepare the case thoroughly; (2) being experts - students need not only to study the case's subject matter in depth but also to acquire necessary skills such as teamwork, communication and negotiation, and (3) taking risks - making decisions that may not be correct, the best or the only possible ones, as in many cases there are several valid solutions.

Besides the huge importance of creativity in this industry, the current characteristics and challenges of fashion businesses also represent quite a convincing argument when the appropriateness of the case method in fashion business education is assessed. These characteristics include the growing importance of speed and time to market, the need for control over the continually increasing number of collections, the need for logistics and retail operations that function well, and more informed and increasingly demanding consumers. Therefore, fashion companies must adapt quickly to the breakneck speed with which everything is changing, as being flexible and adaptive is key to survival nowadays (Chan and Chan, 2010) and we believe that training fashion business students - who eventually will be working for these companies in this way of thinking, evaluating and deciding can help prepare them for the challenging situation the industry faces.

Accordingly, these two facts or arguments - the importance of creativity not only in fashion design but also in fashion business, and the need for fashion business leaders to be trained to be flexible, adaptable and quick decision-makers - should be sufficient at least for the case method to be taken very much into account when teaching in fashion (business) schools.

Moreover, at our school, we have noticed the need in fashion companies for training of their current staff too on these issues related to the management of creativity and the other components previously discussed. For this reason we are also implementing this method of teaching in the custom programs that we organize specially for some fashion companies.

This idea of achieving a mix between business and creativity in fashion schools is not only ours but also that of other prestigious fashion schools around the world. As the 2015 article "Balancing Business and Creative Learning" - on The Business of Fashion (BoF) website - shows, in the previous three years a fashion school of such standing as Parsons had restructured its undergraduate curriculum completely in order to "bring business and creative teaching closer together." That makes us think of the importance and real preoccupation of fashion schools in providing multidisciplinary teaching and the need to prepare students for ever-changing professional careers across departments and job positions. As the executive dean of Parsons, Joel Towers, said: "There's a shift occurring where students realize business is becoming more creative, and they want to go deeper and merge business and creativity more" (Abnett, 2015). 


\section{OUR EXPERIENCE USING THE CASE METHOD}

We started developing case studies for our fashion business school programs following the example of IESE, a business school at our same university - founded in 1958 and inspired by Harvard Business School. Due to this business school's international prestige and its expertise in developing business cases for very different subjects and industries, we saw an excellent opportunity to learn from it and together write interesting cases specific to the fashion industry.

The main idea behind this initiative was not only to have material to use in our courses but mostly the important research that has to be done and the huge possibilities this would bring to help a lot of companies in the industry. And, as a business school, we are very focused on the practical side of academic research.

Therefore, we wanted to share our commitment to this task and both convince and encourage other fashion schools (not only focused on business management) to develop more cases that could be interesting and useful for the whole industry.

\subsection{What We Have Learned So Far}

One of the first things we realized was that different types of cases could be found and thus applied to the industry. The main difference between them is the source of the available information, but it may also depend on the issue involved in the case or the approach taken, the problem assessed, and the company on which the case is based. We explain (see Appendix 1) some of the most typical ones (Roberts, 2001). The most common type is the company field case, which is developed with the cooperation of the company protagonist; it usually includes interviews and firsthand information and requires the approval of the company's executives. Another type is the individual field case, which is usually written from the viewpoint of specific individuals and/or is about their own experiences and is based on information related to a company with which the individuals concerned were once associated. Another type is the general experience case, in which the story is usually made up by a teacher or professor who is an expert in the field or subject treated, so the case is basically based on the author's general knowledge of the topic. This kind of case is used more to deal with low-level or basic issues than with complex situations that need a high level of detail. Finally, we also find the published-information-based case, which is developed from information found in published sources such as magazines, newspapers, research reports and company reports and does not need to be approved by the company.

In our business school we have used all these types and, based on our experience, the most difficult and tough one - but the most interesting and attractive in terms of industry practitioners' involvement and the richness of the information and learning - is the company field case. Some drawbacks we have found when developing this type of case are that it takes a long time for them to get published and be ready to use - a disadvantage in this fast-evolving industry - and that fashion companies are still very reluctant to share information due to the fierce competition there is in the market. In the end this affects the amount and quality of information given in the case and means the information can be also biased.

It is also very important to keep in mind that, no matter which type of case is used, a teaching note should always accompany it. The teaching note acts as a guide for faculty members - in the same university or a different one - who want to teach the case in their courses. Thus, it is imperative that the case authors themselves think about the teaching note almost from the beginning, highlighting the important parts of the case, the most relevant information to bear in 
mind, how to present it in class, what to ask the students in order to foster their independent thinking and eventual learning, etc.

Another key piece of advice is that we should not forget to update the case, especially when it deals with a topic that is very much in vogue in the industry. And, precisely in cases based on fashion companies, this is a fundamental tip to bear in mind since, as we explained above, these companies - and the whole industry - are developing and changing in leaps and bounds. Thus, it is important to keep following up on the situation or problem discussed in the case in order to be up to date at all times and to offer students the latest knowledge coming directly from the industry.

Finally, we would like to add that, depending on the academic program in which it is used and mostly on the background studies or work experience of the students, the goals of the same case may vary as well as what students learn from it. This is also particularly important when we talk about fashion companies, where we can find a lot of different types of student with completely different ways of learning in the same class.

\subsection{Three Examples of Fashion Business Cases}

We have written several case studies based on different challenges or problems faced by fashion companies. However, in order to illustrate what has been mentioned above and to show the usefulness or otherwise of the method, we have chosen three case studies, which can be complementary examples of what we are doing. We wanted to show three cases, and the criteria used for choosing them were: (1) the type of case - we wanted to show various possibilities when it comes to writing case studies about fashion companies, and (2) the topic or subject - each of the case studies was written with different pedagogical goals, and the three cases are used in different specific course subjects.

The three cases selected as examples are the following:

1. “The Loewe Group: A New Industrial Model and Commitment to Lean Management?”

2. "Rita Rodier: un éxito de ventas” (“Rita Rodier: A Sales Success”)

3. “Abercrombie \& Fitch: No es marca para feos” (“Abercrombie \& Fitch: It’s Not a Brand for Ugly People")

More information - the abstract and the learning goals - about each of them is summarized in the table in Appendix 2. As the table also shows, the two criteria noted above have guided the selection - the type of case used and the topic or subject that is taught.

On the one hand, as we can see in the table, following the first criterion defined above, each of them is one "type of case": the first one is a company field case, developed with the help of the company protagonist in the case and containing firsthand information on what really happened; the second one is an individual field case, written directly from the personal experience of one of the authors but keeping secret the protagonist of the case as well as the company by using pseudonyms; and the third one is of the published-information-based case type as the whole case study was inspired by and written using different sources of secondary information such as newspapers, magazines, the company website and financial reports.

On the other hand, concerning the second criterion, each case study "belongs" to a different course or subject, and they have different learning goals (Appendix 2): the first case would fit better in a fashion operations management course and everything to do with the organization of 
fashion production and the supply chain; the second one was developed for use in a learning context to do with human resources management in fashion, specifically in the area of sales and retail where human management must take into account a lot of critical variables and can be very challenging; and finally, the third one was prepared for a course on business ethics in fashion in which we wanted to analyze and investigate the case of a company that, in the past few years, had suffered the consequences of some controversial internal policies.

Therefore, we can see that different types of cases can be used and different fashion management subjects or courses can be covered or taught by means of case studies.

As we can also see summed up in Appendix 2 and in more detail in Appendix 3, the general feedback from students that have used these case studies is very positive. Some key ideas or comments we can highlight are the following. For instance, concerning the case of the company Loewe in the operations management subject, students said: "It is a very clear example of the real importance of operations management in a fashion company"; "The case is very credible because Loewe was a well-known brand for us and the specific situation [...] is very well described"; and "I hope in the future [...] if I have a job at a managerial level, I will be able to respond well enough if I have to deal with a similar situation." Then, about the Rita Rodier case focused on the subject of human resources management, students said: "[The] high level of detail [...] is a lot of help for understanding the case better and identifying a lot with it. In my opinion the case represents a positive lesson in the subject of human resources management" and "It is a totally realistic case! [It] takes place in a French wedding dress company but it could occur (and it does) in any fashion company focused on the commercial area." And finally, regarding the case of Abercrombie \& Fitch in the field of ethics in fashion, students said: "What you learn [...] is that any worker in this industry - and even more so executives - should have a seriously responsible attitude" and "I knew the company very well but I didn't realize before the huge real implications it had for society and overall for teenagers!"

\section{CONCLUSIONS AND PROPOSALS}

Many more teaching cases about fashion companies can be found that have been developed by other business schools, due to specific problems or success stories, where - independently of the industry in which they happen - the issue raised is also of interest for being taught in a course as part of a general MBA or in other business programs. Therefore, the idea of developing cases focused on this industry might not be new. What we aim to advocate and show in this paper, however, is the appropriateness of the specific use of such cases and the methodology to teach fashion business management and thus prepare future industry leaders on the practical side also.

Then, by sharing three of our cases as examples, which have already been used in three different subjects, we show some of the benefits that can be gained by students. One accepted benefit is that cases force students to think from an analytic and managerial perspective. They also challenge students to learn how to debate a specific topic and problem and how to communicate their points of view. Other skills such as team working and decision-making can also be developed, and something else that is very important is that students can acknowledge what can be done and - sometimes even more importantly - what can't. All these benefits, among others, are possible mainly due to the students' high degree of personal identification with the case protagonist and decision-maker in the different situations faced in each of the cases. As we 
explain in the first part of the paper, this is a very important factor in the case method's effectiveness when it comes to trying to achieve business learning objectives.

Nevertheless, there are also some limitations. One of the most important is that, in order to provide high-level learning using this methodology, it is imperative to take care of the quality of cases developed and prevent them from being too descriptive. They must pose an interesting problem to be discussed, promoting a rich debate and creative thinking among the students as they seek to propose a solution or make a decision. Another limitation of this paper is that, when attempts were being made to prove how well the methodology worked for fashion business studies, the questionnaire was done with a small number of students. Nonetheless, we would like to translate this limitation into a proposition for future research into this issue, to extend the questionnaire to a larger number of students in order to make it more statistically valid.

Finally, challenging these limitations, we still encourage other fashion schools first to try to use this methodology - if they are not doing so already - and then to start developing case studies that can help students see different situations they might encounter in the future and also to be engaged in continuous learning about the key topics of the industry in a practical way relating to decision-making. We believe the fashion industry is going through one of its most profound changes ever right now and it may be a good time to learn from those companies that are doing well but also from those that are not achieving good results or are suffering as they try to succeed or just stay afloat. 


\section{REFERENCES}

Abnett, K. (2015), "Balancing Business and Creative Learning,"

http://www.businessoffashion.com/articles/education/balancing-business-and-creative-learning.

Applegate, L. M. (1995), "Case Teaching at Harvard Business School: Some Advice for New Faculty.” Harvard Business School technical note 9-189-062.

Argyris, C. (1980), "Some Limitations of the Case Method: Experiences in a Management Development Program.” Academy of Management Review, 5 (2), pp. 291-298.

Bonoma, T. V. (1989), “Learning With Cases.” Harvard Business School technical note 9-589-080.

Chan, F. T., and H. K. Chan (2010), “An AHP Model for Selection of Suppliers in the Fast Changing Fashion Market.” The International Journal of Advanced Manufacturing Technology, 51 (9-12), pp. 1,195-1,207.

Dewing, A. S. (1931), "An Introduction to the Use of Cases." In The Case Method of Instruction. New York: McGraw-Hill. Seen in Garvin, D. A. (2003), "Making the Case." Harvard Magazine, 106 (1), pp. 56-65.

Ellet, W. (2007), "How to Discuss a Case.” In Ellet, W. (2007), The Case Study Handbook. Boston, MA: Harvard Business School.

Garvin, D. A. (2003), “Making the Case.” Harvard Magazine, 106 (1), pp. 56-65.

Golich, V. L. (2000), “The ABCs of Case Teaching.” International Studies Perspectives, 1 (1), pp. 11-29.

Gragg, C. I. (1940), “Because Wisdom Can't Be Told.” Harvard Alumni Bulletin, 19. Seen in Applegate, L. M. (1995), "Case Teaching at Harvard Business School: Some Advice for New Faculty.” Harvard Business School technical note 9-189-062.

Roberts, M. J. (2001), "Developing a Teaching Case (Abridged).” Harvard Business School technical note 9-901-055.

Santagata, W. (2004), "Creativity, Fashion and Market Behavior." Routledge Studies in International Business and the World Economy, 33, pp. 75-90.

Yeaple, R. (2012), Is the MBA Case Method Passé? Available at http://www.forbes.com/sites/ronaldyeaple/2012/07/09/is-the-mba-case-method-passe/. 


\section{Appendix 1}

Types of Case

\begin{tabular}{|l|l|}
\hline TYPE OF CASE & DEFINITION \\
\hline Company field case & $\begin{array}{l}\text { This is based on a real problem faced by a company and is usually } \\
\text { developed with its support and cooperation. It may include } \\
\text { firsthand information and sometimes it needs the approval of the } \\
\text { company's executives. }\end{array}$ \\
\hline Individual field case & $\begin{array}{l}\text { This is based on the author's personal experience of a company, } \\
\text { for which a pseudonym is usually used in the case study to keep its } \\
\text { identity a secret. It does not require validation to be published. }\end{array}$ \\
\hline Published-information-based case & $\begin{array}{l}\text { This is based on real information found in different public sources, } \\
\text { such as published reports, magazines and newspapers, and it } \\
\text { does not need the company's approval. }\end{array}$ \\
\hline General experience case & $\begin{array}{l}\text { This is a case based on a story that has been made up by a } \\
\text { teacher who is an expert in the field or subject treated in the case. } \\
\text { It is used more for basic issues rather than for complex situations. }\end{array}$ \\
\hline
\end{tabular}




\section{Appendix 2}

\section{Case Summaries}

\begin{tabular}{|c|c|c|c|c|c|}
\hline TITLE & $\begin{array}{l}\text { TYPE OF } \\
\text { CASE }\end{array}$ & ABSTRACT & $\begin{array}{c}\text { MAIN } \\
\text { SUBJECT/COURSE }\end{array}$ & LEARNING GOALS & STUDENTS' FEEDBACK \\
\hline $\begin{array}{l}\text { "The Loewe } \\
\text { Group: A New } \\
\text { Industrial } \\
\text { Model and } \\
\text { Commitment to } \\
\text { Lean } \\
\text { Management?" }\end{array}$ & $\begin{array}{l}\text { company field } \\
\text { case }\end{array}$ & $\begin{array}{l}\text { Loewe is one of the brands of } \\
\text { the LVMH group, particularly } \\
\text { well known for its leather } \\
\text { goods. Loewe has its own } \\
\text { factories and also uses external } \\
\text { suppliers to manufacture its } \\
\text { products. In this case, company } \\
\text { management must decide } \\
\text { whether to move toward the } \\
\text { industrial model of the LVMH } \\
\text { group's other brands and fully } \\
\text { outsource production or instead } \\
\text { convert its main factory into a } \\
\text { center of excellence capable of } \\
\text { generating a competitive } \\
\text { advantage for the company. }\end{array}$ & $\begin{array}{l}\text { FASHION } \\
\text { OPERATIONS } \\
\text { MANAGEMENT }\end{array}$ & $\begin{array}{l}\text { a) how operations can } \\
\text { also be a source of } \\
\text { competitive strategy for } \\
\text { a fashion brand. } \\
\text { b) operations not only } \\
\text { take into account time, } \\
\text { processes and } \\
\text { machines ("physics") } \\
\text { but also workers' } \\
\text { motivation ("chemistry"). } \\
\text { c) poor control of } \\
\text { operations in a fashion } \\
\text { company can make the } \\
\text { brand and product as } \\
\text { well as the company's } \\
\text { economic success } \\
\text { suffer eventually. }\end{array}$ & $\begin{array}{l}\text { "It is a very clear example of } \\
\text { the real importance of } \\
\text { operations management in a } \\
\text { fashion company." } \\
\text { "I hope in the future [...] if I } \\
\text { have a job at a managerial } \\
\text { level, I will be able to respond } \\
\text { well enough if I have to deal } \\
\text { with a similar situation." } \\
\text { "I can't really see a negative } \\
\text { point. [...] The case is very } \\
\text { credible because Loewe was a } \\
\text { well-known brand for us and } \\
\text { the specific situation [...] is } \\
\text { very well described." }\end{array}$ \\
\hline $\begin{array}{l}\text { "Rita Rodier: A } \\
\text { Sales Success" }\end{array}$ & $\begin{array}{l}\text { individual field } \\
\text { case }\end{array}$ & $\begin{array}{l}\text { This case deals with the } \\
\text { dilemma of a "perfect } \\
\text { salesperson" and her rise } \\
\text { within the organization. It } \\
\text { reflects how the protagonist } \\
\text { and salesperson, Rita Rodier, } \\
\text { has a lot of ability when it } \\
\text { comes to selling but lacks team } \\
\text { management ability. Moreover, } \\
\text { her closeness to company } \\
\text { management, through informal } \\
\text { relationships, makes it even } \\
\text { more difficult for her to fit in as } \\
\text { an executive. }\end{array}$ & $\begin{array}{l}\text { HUMAN } \\
\text { RESOURCES } \\
\text { MANAGEMENT IN } \\
\text { FASHION }\end{array}$ & $\begin{array}{l}\text { a) how to manage a } \\
\text { trade-off situation in } \\
\text { which a person that is } \\
\text { key in the organization } \\
\text { in terms of revenues } \\
\text { achieved is not good at } \\
\text { other important } \\
\text { organizational tasks. } \\
\text { b) how to analyze the } \\
\text { sales incentives } \\
\text { structure in a fashion } \\
\text { company and the } \\
\text { motivations that they } \\
\text { awaken. } \\
\text { c) how to deal and } \\
\text { manage the } \\
\text { professional career in } \\
\text { retail taking into account } \\
\text { different competences, } \\
\text { not only sales. }\end{array}$ & $\begin{array}{l}\text { "[The] high level of detail [...] is } \\
\text { a lot of help for understanding } \\
\text { the case better and identifying } \\
\text { a lot with it. In my opinion the } \\
\text { case represents a positive } \\
\text { lesson in the subject of human } \\
\text { resources management." } \\
\text { "[It] is related to an interesting } \\
\text { and current issue that happens } \\
\text { a lot in companies, which is } \\
\text { the brain drain issue." } \\
\text { "It is a totally realistic case! It } \\
\text { takes place in a French } \\
\text { wedding dress company but it } \\
\text { could occur (and it does) in } \\
\text { any fashion company that is } \\
\text { very focused on the } \\
\text { commercial area." }\end{array}$ \\
\hline $\begin{array}{l}\text { "Abercrombie \& } \\
\text { Fitch: It's Not a } \\
\text { Brand for Ugly } \\
\text { People" }\end{array}$ & $\begin{array}{l}\text { published- } \\
\text { information- } \\
\text { based case }\end{array}$ & $\begin{array}{l}\text { Abercrombie \& Fitch (A\&F) was } \\
\text { founded in } 1893 \text { in the United } \\
\text { States as a store selling } \\
\text { camping items and weapons. In } \\
1988, \text { it was acquired by The } \\
\text { Limited, creator of other } \\
\text { successful brands such as } \\
\text { Victoria's Secret. In order to } \\
\text { revive the brand and give it a } \\
\text { new look, Mike Jeffries was put } \\
\text { in charge and, over more than } \\
\text { a decade, he managed to } \\
\text { renew it until it became what it } \\
\text { is today. His obsession with } \\
\text { beauty and physical } \\
\text { appearance turns out to be the } \\
\text { brand's competitive advantage } \\
\text { and the strategy's main pillar, } \\
\text { which is reflected in customers, } \\
\text { employees, stores, products, } \\
\text { etc. However, the company has } \\
\text { been involved in several } \\
\text { controversies and has been } \\
\text { accused repeatedly of } \\
\text { discrimination. }\end{array}$ & $\begin{array}{l}\text { BUSINESS ETHICS } \\
\text { IN FASHION }\end{array}$ & $\begin{array}{l}\text { a) how the leader of a } \\
\text { fashion company can } \\
\text { have a significant } \\
\text { impact on the } \\
\text { company's culture and } \\
\text { values, which are } \\
\text { reflected in the } \\
\text { company's policies and } \\
\text { practices. } \\
\text { b) the influence that the } \\
\text { ethically disputed } \\
\text { lifestyle and values } \\
\text { communicated by a } \\
\text { brand can have on } \\
\text { young customers. } \\
\text { c) the implications of } \\
\text { unethical and } \\
\text { discriminatory policies } \\
\text { for employee behavior } \\
\text { and human } \\
\text { development. }\end{array}$ & $\begin{array}{l}\text { "What you learn [...] is that any } \\
\text { worker in this industry - and } \\
\text { even more so executives - } \\
\text { should have a seriously } \\
\text { responsible attitude." } \\
\text { "I knew the company very well } \\
\text { but I didn't realize before the } \\
\text { huge real implications it had } \\
\text { for society and overall for } \\
\text { teenagers!" } \\
\text { "A very positive thing about } \\
\text { this case is that it poses the } \\
\text { question of responsibility not } \\
\text { regarding environmental } \\
\text { issues [...] but regarding the } \\
\text { social part [...] that is, the } \\
\text { people who are around the } \\
\text { brand: customers and } \\
\text { employees." }\end{array}$ \\
\hline
\end{tabular}




\section{Appendix 3}

Students' Responses to the Questionnaire

\section{CASE 1: "The Loewe Group: A New Industrial Model and Commitment to Lean Management?"}

Author: "Do you think the Loewe case shows a possible real situation happening in the industry in the operations field? Think about positive and negative aspects of the case methodology applied to this specific field of study."

Student 1: "The Loewe case study perfectly illustrates what business operations in the fashion industry are about. It is also a very clear example of the real importance of operations management in a fashion company, showing how a great part of business success relies on how to organize employees to achieve faster production and more motivated work. [...] However, although I believe that the case method is a good method when identifying a problem and analyzing a real situation, I think it would be a good idea to have some theoretical classes in the subject before starting to prepare the case, in order to be able to apply the concepts when analyzing it and to take full advantage of it."

Student 2: "The Loewe case seemed to me a very good real example for studying operations management of a company in the fashion industry. I hope in the future, after finishing the MBA, if I have a job at a managerial level, I will be able to respond well enough if I have to deal with a similar situation in a company. [...] It made me realize that sometimes in a company the main problems can happen at the industrial operations level, maybe production controls are not being done correctly, or we are wasting time and causing a harmful delay, etc. So, we cannot lose sight of the operations."

Student 3: "Personally, I do not think I will ever work in the operational area of a company but I must say this case illustrates very well how to make a decision in a fashion company, especially in a trade-off like the one faced by this company, in which a completely handmade product could become semi-industrial and more competitive without losing quality. [...] I can't really see a negative point. [...] The case is very credible because Loewe was a well-known brand for us and the specific situation in which it found itself is very well described in it. A lot of details are given and you can appreciate the collaboration or support of the company, which gives you more commitment and self-involvement." 


\section{Appendix 3 (Continued)}

\section{CASE 2: "Rita Rodier: A Sales Success"}

Author: "Do you consider that this case illustrates a situation that you may encounter in your current or future job in a fashion company? Do you think the problem shown is important and that it usually happens? Think about positive and negative aspects of the case method applied to this specific field of study."

Student 1: "Well, the Rita Rodier case... I find it is a very illustrative case. It is about the management of sales staff in retail, which is usually a tough and challenging task in fashion (retail) companies. In this case, it's not about the corporate structure of the company but it is focused specifically on people management in the commercial and sales area. The wording of the case is like a story with conversations between the protagonists and a high level of detail, which is a lot of help for understanding the case better and identifying a lot with it. In my opinion the case represents a positive lesson in the subject of human resources management. [...] Maybe it occurs to me that the lesson could be improved if the students received a little previous theoretical explanation of the main ideas and practices in this field, in order to cope with the case better and make the most of it."

Student 2: "The Rita Rodier case is related to an interesting and current issue that happens a lot in companies, which is the brain drain issue. HR departments play a very important role when it comes to noticing and managing a talented person and helping him or her find the right hole in the company, taking into account their abilities and skills. Thus, the case shows the importance of managing the motivation of your employees, acknowledging that poor management may lead the right person to leave the company. In the case of Rita, she is a person who has excellent commercial abilities but needs to promote other skills. [...] As a point for improvement, I think it would be very useful to have an introduction before the class about the different job profiles a human resources department has to manage and how to identify them in an organization. It would also be interesting to understand and learn about strategies to motivate staff."

Student 3: "It shows very well typical behavior we can find in a lot of fashion companies in the retail area. It deals with the issue of how to manage talented people and what we should do to retain this talent. It is a totally realistic case! It takes place in a French wedding dress company but it could occur (and it does) in any fashion company that is very focused on the commercial area in which the store is the core center of the business. [...] The case is very detailed and realistic and it shows perfectly the kind of leadership in the company and how it has changed through the second generation of the family business. I found it easy to understand and I found it very interesting to learn about how to manage talent and key people in a company." 


\section{Appendix 3 (Continued)}

\section{CASE 3: "Abercrombie \& Fitch: It's Not a Brand for Ugly People"}

Author: "Do you think the A\&F case presents a real situation that can be found in the fashion industry? Do you think the issue it discusses is important to bear in mind when studying fashion business management? Think about positive and negative aspects of the case method applied to this specific field of study."

Student 1: "I believe that, for the course of ethics in the fashion business, it is a perfect and wise case as it makes you reflect on the importance of the decisions in terms of values of the brand, internal policies and marketing strategy that a manager has to make in a company and the direct impact it may have on society. It is definitely a very closed and real case applicable also to any other company. [...] What you learn with this case is that any worker in this industry - and even more so executives - should have a seriously responsible attitude when it comes to decisions that can have a direct impact on people's lives and especially in this case with the values transmitted to teenagers."

Student 2: "I knew the company very well but I didn't realize before the huge real implications it had for society and overall for teenagers! Sometimes, and this happens a lot in the fashion business as it is very centered on the product, design and experiences, we lose sight of the possible consequences (good or bad) that a brand can have later on... So, I think this case shows a very important topic to address in the fashion business, as it is something we (as future leaders) will have to bear in mind. The only problem or negative point I could find in the case method applied to ethics is that it is a very subjective topic and you find that not everybody thinks the same way, so the discussion in class may not achieve a final common opinion and, if the teacher doesn't conduct the discussion very well, it can end up in a kind of fight. Nevertheless, it is very interesting as it is at the same time a more open topic and different opinions can be contrasted and a very rich conversation can take place in class."

Student 3: "It is true that brands usually face problems related to their value proposition. And for instance the problem with sizes in fashion - which is also addressed in this case - are the order of the day. That's why we will have to take it into account when working for the industry as this usually has a huge media impact and the brand may be damaged. So, thinking about the consequences for society and even how to face them is key. In particular, the A\&F case shows clearly the power fashion has and that talking about fashion is also talking about identity. Therefore, there is an influence and it plays a bigger role among young people who are still more vulnerable as they are constructing the idea they have of themselves. [...] A very positive thing about this case is that it poses the question of responsibility not regarding environmental issues which are also very important - but regarding the social part that sometimes is forgotten - that is, the people who are around the brand: customers and employees. And for an idea to improve the methodology in this subject I think it would be interesting for the teacher to finish the discussion with a wrap-up or basic final ideas that could be applicable to other specific business cases." 